\title{
ВЛИЯНИЕ ОРТОДОНТИЧЕСКОГО ЛЕЧЕНИЯ НА СОСТОЯНИЕ ТКАНЕЙ ПАРОДОНТА (ОБЗОР ЛИТЕРАТУРЫ)
}

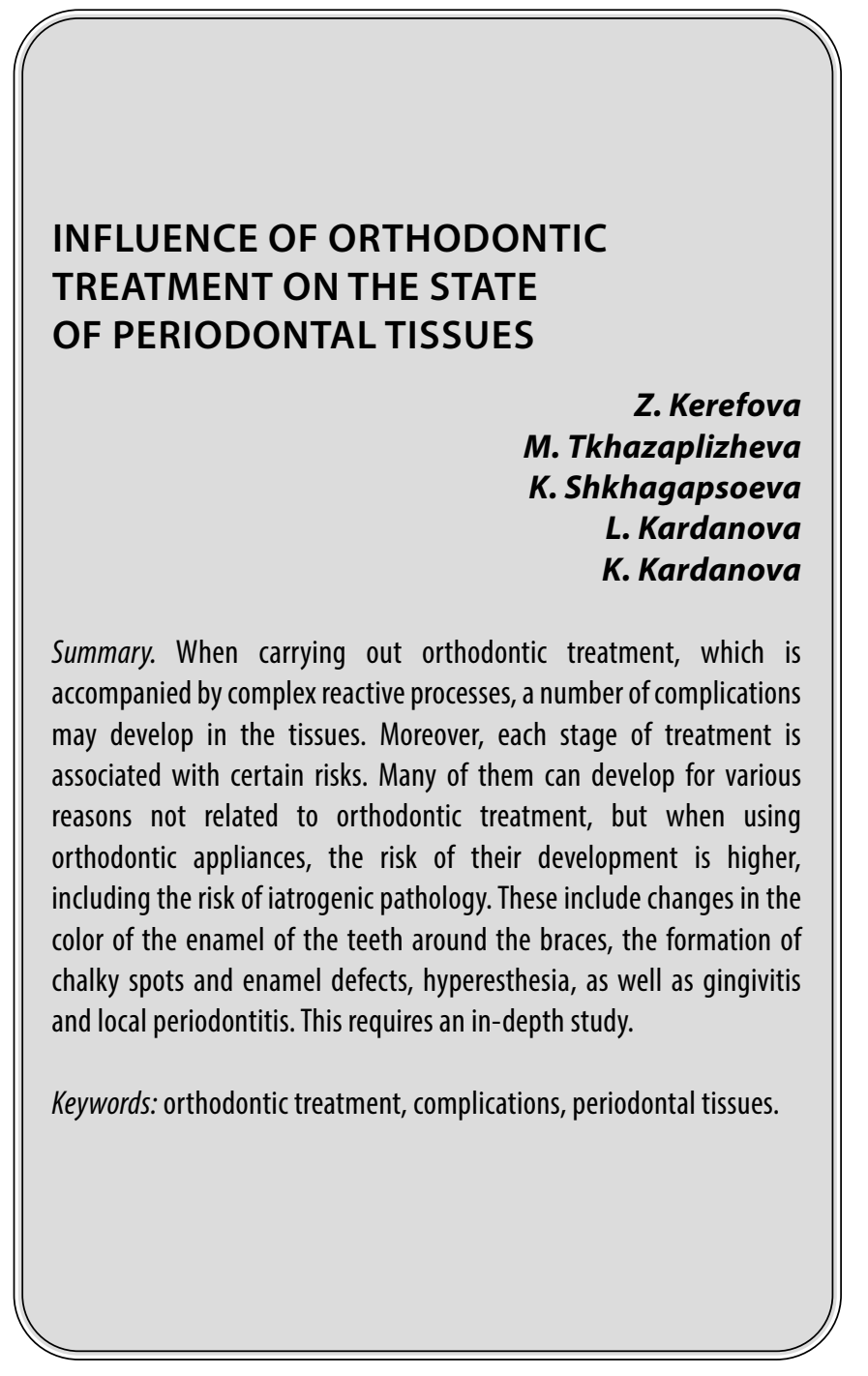

A номалии зубочелюстной системы широко распространены среди взрослого населения. По данным ранее проведенных исследований распространенность зубочелюстных аномалий среди взрослого населения составила $82 \%$. В результате эпидемиологического исследования была выявлена высокая нуждаемость в ортодонтическом и ортопедическом лечении обследованных в возрасте 18-45 лет. В группе 18-25 лет частота зубочелюстных аномалий составила $40,7 \%$, дефектов зубных рядов - 27,18\%. В группе $26-$ 45 лет зубочелюстные аномалии встречаются в 68,96\%, дефекты зубных рядов - в 75,86\% случаев. В последнее время к врачу-ортодонту довольно часто обращаются пациенты с зубочелюстными аномалиями в возрасте
Керефова Зарина Витальевна Аспирант, ФГБОУ ВО «Кабардино-Балкарский государственный университет им. Х.М. Бербекова»

zarinakeref@mail.ru

тхазаплижева Марина Тулевна

К.м.н., дочент, ФГБОУ ВО «Кабардино-Балкарский государственный университет им. Х.М. Бербекова» mar_tul25@mail.ru

Шхагаnсоева Карина Аслановна

Ассистент, ФГБОУ ВО «Кабардино-Балкарский государственный университет им. Х.М. Бербекова» Karina.denta@mail.ru

Карданова Лариса Владимировна

К.м.н., дочент, ФГБОУ ВО «Кабардино-Балкарский государственный университет им. Х.М. Бербекова» kard-77@yandex.ru

Карданова Карина Хасанбиевна

К.м.н., дочент, ФГБОУ ВО «Кабардино-Балкарский государственный университет им. Х.М. Бербекова» kardanovakarina@mail.ru

Аннотация. При проведении ортодонтического лечения, которое сопровождается сложными реактивными процессами, в тканях возможно развитие ряда осложнений. При этом каждый этап лечения связан с определенными рисками. Многие из них могут развиваться по различным причинам, но при использовании ортодонтических аппаратов риск их развития выше, в том числе и риск возникновения ятрогенной патологии. К ним можно отнести изменения цвета эмали зубов вокруг брекетов, образование меловидных пятен и дефектов эмали, гиперестезия, а также гингивит и локальный пародонтит. Это требует проведения углубленного изучения.

Ключевые слова: ортодонтическое лечение, осложнения, ткани пародонта.

от 18 до 40 лет, с более выраженными клиническими проявлениями патологии прикуса, чем у детей и подростков. Это объясняется тем обстоятельством, что у взрослых пациентов аномалии и деформации часто осложняются частичной потерей зубов, перегрузкой пародонта и деформациями жевательной поверхности. С возрастом частота зубочелюстных аномалий увеличивается, что обусловлено потерей зубов $[14,18]$.

Установлено, что высокая частота аномалий зубочелюстной системы у взрослых связана с высоким распространением аномалий, малым охватом и недостаточной эффективностью их лечения и реабилитации среди детского населения. Серьезные недостатки в организа- 
ции профилактики и лечения аномалий зубочелюстной системы в детском возрасте и, практически отсутствия у взрослого населения, приводят к ранней потере значительного числа зубов и высокой нуждаемости в ортопедической помощи взрослого населения [13].

Ортодонтическое лечение, как способ устранения патологии прикуса и аномалий положения зубов, сопровождается сложными реактивными процессами в тканях и, в тоже время, является фактором риска появления ятрогенной патологии, что требует углубленного изучения [16]. В настоящее время проводятся исследования молекулярных механизмов влияния ортодонтического лечения на состояние тканевых структур пародонта [5].

При проведении ортодонтического лечения, как и при любом методе лечения в медицине, возможно развитие различных осложнений. При этом каждый этап лечения связан с определенными рисками. Многие из них могут развиваться и без лечения, но при использовании ортодонтических устройств риск их развития возрастает [6].

Интенсивное развитие методов ортодонтического лечения пациентов с зубочелюстными аномалиями, а также значительное повышение эффективности несъемной ортодонтической техники не исключили риск возникновения различных осложнений в процессе проводимого лечения у пациентов данной категории, о чем убедительно свидетельствует их высокий процент - от 32,7 до 50\%. К таким осложнения относятся: изменения цвета эмали зубов вокруг брекетов, образование белых пятен и дефектов эмали, гиперестезия отдельных зубов после удаления брекетов, гингивит, пародонтит. Отсутствие адекватной оценки состояния пародонта приводит к обострению уже имеющегося патологического процесса, что является осложнением, которое необходимо своевременно купировать для предупреждения дальнейшего прогрессирования патологического процесса в пародонте. Риск развития осложнений со стороны пародонта при проведении лечения с применением несъемной ортодонтической техники достаточно высок и составляет 20-38\% и выше. Выявлено, что в процессе ортодонтического лечения через 3-4 месяца после фиксации несъемной техники у $27 \%$ пациентов были отмечены воспалительные изменения в тканях пародонта. При обследовании этих пациентов в пришеечной области коронок зубов обнаруживали значительное скопление мягкого зубного налета, отложение зубного камня, отмечали гиперемию и отечность десны, а также ее кровоточивость при зондировании разной степени выраженности. Это является свидетельством развития выраженного воспалительного процесса в тканях пародонта. Наличие в полости рта брекетов, колец, дуг и лигатур значительно затрудняет проведение обычных гигиенических процедур, и тем самым создает условия для развития в пародонте воспалительного процесса. В связи с этим необходима объективная оценка состояния тканей пародонтального комплекса с использованием цитоморфометрии до лечения, во время и после лечения и проведение необходимой терапии для предупреждения или купирования уже развившихся воспалительных осложнений. Столь частое развитие осложнений, определяющих высокую актуальность этой проблемы, требует к себе самого пристального внимания в плане своевременной диагностики и лечения совместно со специалистами смежных специальностей (в частности, пародонтолога) [2,6].

Присутствующая в полости рта ортодонтическая аппаратура определяет два направления изменений в пародонте. Первое заключается в физиологическом преобразовании пародонтальных ультраструктур, что приводит к передвижению зубов в нужной ориентации; второе - отрицательное воздействие экзогенных и эндогенных факторов, а именно: общесоматический статус, в частности гормональный фон; гигиеническое состояние полости рта и др. [4].

Лечение зубочелюстных аномалий и деформаций проводят с помощью съемной и несъемной ортодонтической техники. Состояние тканей пародонта при ортодонтическом лечении с применением несъемной аппаратуры определяют 3 основных фактора: перестройка структур, связанная с перемещением зубов; общесоматический статус, гигиеническое состояние полости рта.

На все различные воздействия организм всегда реагирует как единая сложная система. В ответ на механическое раздражение ортодонтическими аппаратами различных конструкций, в клетках тканей возникает возбуждение. Это возбуждение представляет собой сложную биологическую реакцию, которая проявляется в совокупности физических, физико-химических, химических процессов и функциональных изменений. Под воздействием ортодонтических аппаратов, на различных этапах лечения, возникающие процессы рассасывания и построения костной ткани, протекают одновременно, с преобладанием того или иного процесса [25].

Ортодонтическое лечение, направленно на исправление аномально расположенных зубов, их скученности, нормализацию прикуса и преследует цель равномерного распределения жевательной нагрузки на пародонт. Наряду с этим оно является фактором, провоцирующим заболевания пародонта вследствие ухудшения гигиены полости рта при ношении ортодон- 
тической аппаратуры, а также перемещения зубов. Это влияет на состояние окружающих зубы тканей и в ряде случаев вызывает развитие таких осложнений как хронический катаральный и гипертрофический гингивит, пародонтит. Клинически значимые осложнения ортодонтического лечения встречались у 32,32\% пациентов, обратимые осложнения определялись в 18,77\% случаев, необратимые нарушения выявлялись у 13,54\% обследованных. Осложнения, связанные с применением съемных аппаратов, наблюдались у 24,72\% больных, осложнения при использовании несъемной ортодонтической техники встречались у $36,55 \%$ обследованных пациентов [24].

На основании клинических и цитоморфометрических исследований установлено, что в процессе ортодонтического лечения несъемной техникой в 27,6\% выявляются воспалительные процессы в тканях пародонта: хронический генерализованный гингивит $(13,4 \%)$, хронический гипертрофический гингивит (10\%) и хронический генерализованный пародонтит лёгкой степени тяжести (4,2\%) [19].

В результате исследования было выявлено, что под влиянием механического воздействия, возникающего при установке несъёмной ортодонтической техники в десневой жидкости через месяц и год после начала ортодонтического лечения происходят процессы тканевой перестройки периодонтальной связки и альвеолярного отростка. В течение месяца воздействие ортодонтических сил приводит к сдавливанию периодонтальной связки и, в результате, изменению кровообращения в ней и на уровне альвеолярного отростка, а также к резорбции прилежащей стенки зубной альвеолы остеокластами. Это сопровождается развитием гипоксии и выбросу в десневую жидкость факторов, способствующих усилению ангиогенеза (ФРЭС, ФРФ), так и понижающих его активность (ИЛ-12). Изменения содержания факторов ангиогенеза в десневой жидкости, возникающие после установки ортодонтического аппарата, являются характеристикой процессов перестройки тканевых структур, окружающих зуб. Подъемом уровня ФРЭС выше 33 пг/мл через месяц после начала ортодонтического лечения определяет необходимость изменения тактики лечения, в основе которой лежит снижение механической нагрузки на зубодесневое соединение. Процессы ремоделирования тканей пародонта, которые развиваются при ортодонтическом лечении, в течение года вызывают развитие осложнений на уровне зубодесневого соединения в результате активации воспалительных процессов. У пациентов наблюдается увеличение показателей индексной оценки состояния тканей пародонта. В десневой жидкости нарастает содержание нейтрофильных лейкоцитов и дегенеративных форм эпителиоцитов, концентрации основной группы провоспалительных и остеогенных цитокинов, факторов ангиогенеза [5].

Исследования показали, что через 1 неделю после установки брекет-системы ортодонтическая коррекция приводит к стимуляции воспалительного процесса в пародонте. Это проявляется в повышении концентрации противовоспалительных цитокинов (ИЛ $1 \beta$ и ИЛ 4) на 64,1\% и 4,2\% и их нормализации через 4-12 недель. Подавление факторов местного иммунитета с уменьшением активности лизоцима и концентрации slgA происходит на протяжении 12 недель после установки брекет-системы [11].

Результаты исследования показали, что ортодонтическое лечение приводит к активизации воспалительного процесса в тканях пародонта на седьмые сутки после фиксации несъемной аппаратуры, что подтверждается ростом значений индекса РМА, Парма, ростом индекса кровоточивости и увеличением концентрации прои противовоспалительных цитокинов ИЛ-13 и ИЛ-4 на $64,1 \%$ и 4,2\%, соответственно. Развивается гингивит. Также было выявлено, что ортодонтическое лечение способствует снижению уровня гигиены полости рта на седьмые сутки после фиксации несъемной аппаратуры на 26,8\%. В ходе ряда поведенных исследований состояния гуморального и клеточного иммунитета, было выявлено, что в процессе ортодонтического лечения возникает иммунодефицитное состояние. Об этом свидетельствуют снижение уровня лимфоцитов CD3, иммуноглобулина А и изменение иммунорегуляторного индекса. При проведении ортодонтического лечения подавляются факторы местного иммунитета полости рта со снижением активности лизоцима и концентрации slgА в смешанной слюне в течение 3-х месяцев после фиксации несъемной аппаратуры [15,26].

Перестройка структур пародонта во время перемещения зубов является неестественно вызванным процессом, но реорганизация тканей физиологична только при воздействии оптимальной нагрузки. Данный факт, а также нехватка объективных критериев, воздействующих на зуб сил, приводят к перегрузке пародонта, выражающейся патологической реакцией тканей десны и костных структур. Вначале происходит воспаление десны с отеком, гиперемией, а в дальнейшем возникают пролиферативные процессы в эпителии и собственной пластинке слизистой оболочки. Это связано, также, с воздействием таких микроорганизмов, как: Actinobacillus actinomycetemcomitans, Prevotella intermedia, Porphyromonas gingivalis, Bactericides forsythus. Actinobacillus actinomycetemcomitans и является маркером прогрессирующей деструкции костной ткани, имеющим значимую роль в появлении агрессивных форм пародонтита [4,8]. 
Ортодонтическое лечение пациентов с завершенным скелетным ростом требует качественно новых подходов к планированию и лечению [12].

У лиц со сформировавшейся зубочелюстной системой, увеличиваются сроки ортодонтической коррекции, и в связи с этим значительно возрастают риски развития осложнений [9]. При увеличении сроков ортодонтической коррекции, сопровождающееся перегрузкой зубов, зачастую возникают тяжелые осложнения со стороны тканей пародонта, что вызвано сдавлением и тромбозом сосудов, и расстройством венозного кровообращения. Механическое воздействие конструкций приводит к изменению микроциркуляционного русла пародонта. Максимальные изменения отмечены на капиллярном уровне и выражаются в уменьшении скорости кровотока и возникновении гипоксии [21].

Как говорилось выше, использование различных ортодонтических конструкций значительно влияет на клиническое, функциональное, а также гигиеническое состояние полости рта [24]. В процессе аппаратного ортодонтического лечения зубочелюстных аномалий и деформаций в полость рта на длительное время вводятся несъемные аппараты, которые могут нарушать гомеостаз и оказывать негативное воздействие на органы и ткани зубочелюстной системы. Конструктивные элементы аппаратов (кольца, дуги, брекеты, лигатуры) являются дополнительными пунктами ретенции налета, поэтому за счет ухудшения процессов самоочищения, нарушения динамического равновесия и обменных процессов при ортодонтическом лечении ухудшается гигиеническое состояние полости рта, возникают воспалительные явления в тканях пародонта, возрастает поражаемость зубов кариесом [1].

Клинико-рентгенологическое обследование больных, пользующихся дуговыми ортодонтическими аппаратами с замковыми креплениями, фиксирующимися на оральной поверхности зубов, позволило определить достоверное ухудшение гигиены полости рта уже через 3-6 месяцев после наложения конструкции, что сопровождалось снижением уровня гигиены самого протеза и нарастанием воспалительных изменений в тканях пародонта [3].

Результаты микробиологических исследований свидетельствуют о нарушении «экологической» ситуации в полости рта у больных в процессе ношения ортодонтических конструкций [17].

В зависимости от характера взаимодействия ионов материала ортодонтической аппаратуры с ферментными системами тех или иных видов бактерий или грибов происходит диспропорциональное изменение коли- чества важнейших компонентов микробиоценоза полости рта. Известно, что некоторые группы бактерий, которые населяют данную экологическую нишу, могут обладать факторами вирулентности и потому быть способными вызывать воспалительный процесс слизистой оболочки полости рта и тканей пародонта.

В зубном налете у пациентов, находящихся на ортодонтическом лечении, были обнаружены различные аэробные и анаэробные микроорганизмы. Среди выделенных аэробов 70\% составляли грамположительные кокки \{Streptococcus viridans - 31\%, Streptococcus spp. - 25\%, Staphylococcus epidermidis $6 \%$, Enterococcus spp.- 4\%, Streptococcus oralis - 4\%), $12 \%$ - грамотрицательные кокки \{Neisseria spp.), 10\% Candida albicans и 8\% - грамположительные палочки \{Corynebacterium spp.). Анаэробные микроорганизмы в 19\% случаев были представлены грамположительными кокками (Peptostreptococcus spp.), грамположительными палочками - всего 30\% \{Lactobacillus spp., Propionibacterium spp., Actinomyces spp.), грамотрицательными палочками -15\% \{Fusobacterium spp.), грамотрицательными кокками - 36\% \{Veillonella spp.) [22].

Комплексное лечение пациентов с воспалительно-дистрофическими заболеваниями пародонта с применением ортодонтических методов требует соблюдения особого алгоритма в планировании, последовательности этапов и дозировке сил [10]. Выявлено, что к возникновению локального воспаления может привести нерациональное ортодонтическое лечение: применение нецелесообразных для больного конструкций ортодонтических аппаратов, использование чрезмерных сил их действия [20].

Можно сделать вывод о том, что у значительной части пациентов, получающих ортодонтическое лечение, воспалительные изменения в пародонте являются его осложнением [7].

Таким образом, ортодонтическое лечение может вызывать побочные патологические явления, что необходимо учитывать врачу, особенно при длительном ортодонтическом лечении и в ретенционном периоде. Проведение ортодонтического лечения в отсутствие адекватной оценки состояния зубочелюстной системы, чрезмерное, неконтролируемое приложение силы к опорным зубам может инициировать воспалительную реакцию пародонта или привести к обострению уже имеющегося патологического процесса.

При длительном ношении несъемного ортодонтического аппарата значительно снижается уровень гигиены полости рта. В связи с этим, во время ортодонтического лечения представляется крайне необходимым проведе- 
ние профессиональной гигиены не реже одного раза в три месяца, т.к. несъемная ортодонтическая аппаратура создает множество ретенционных пунктов для образования мягкого зубного налета, зубных бляшек, и, как следствие, возникновения кариеса, гингивита и пародонтита [22].

Соблюдение правильной, оптимальной гигиены полости рта в процессе проводимого ортодонтического лечения позволит исключить досрочное снятие ортодонтического аппарата, как меру профилактики возникновения и развития патологических изменений в тканях пародонта.

Знания врача о данных процессах позволят правильно спланировать лечение, выбрать ортодонтический аппарат, определить точки опоры, места и величину приложения силы, направление, характер и интенсивность её использования [23].

\section{ЛИТЕРАТУРА}

1. Алимова Р.Г. Индивидуальная гигиена полости рта при применении современных несъемных сложных ортодонтических конструкций // Стоматология. - 2004. - № 6. - С. 63-64.

2. Арсенина 0.И, Григорьян А.С., Фролова О.А., Петрунина 0.В. Диагностика и лечение воспалительных процессов в пародонте, возникших при ортодонтическом лечении // Институт стоматологии. - 2005.— № 1.- С. 50-54.

3. Беньковский, В.В. Клиническая оценка гигиены полости рта пациентов, пользующихся ортодонтическими аппаратами: автореф. дис. .... канд. мед. наук.—СПб., 2011.- 22 C.

4. Бирюков, А.С., Косырева Т.Ф. Влияние механической нагрузки несъемной аппаратуры на ткани пародонта при ортодонтическом лечении // Наука XXI век: сб. науч. тр.- М., 2015.- С. 290-295.

5. Воробьёв Д.В. Обоснование применения профессиональной гигиены полости рта при ортодонтическом лечении по результатам исследования биомаркеров десневой жидкости: дис.. ... канд. мед. наук — Саратов, 2013. - 143 с.

6. Гонтарев, С.Н. Дифференцированное управление заболеваемостью временных зубов на основе геоинформационного, ситуационного анализа, прогнозирования и лечебных инноваций / С.Н. Гонтарев; под ред. проф. Н.М. Агаркова. — Белгород:- 2007.— 224 с.

7. Гонтарев С. Н., Чернышева Ю.А., Федорова И.Е., Гонтарева И.С. Воспалительные заболевания слизистой оболочки полости рта при использовании съемной и несъемной ортодонтической аппаратуры // Научные ведомости. Серия Медицина. Фармация.2013.— № 11.— Выпуск 22/1, — стр.15-17

8. Грудянов А.И. Изменения состава микрофлоры зубодесневой борозды в процессе ортодонтического лечения // Стоматология. - 2012.— № 3. C. 61-64.

9. Децык 0.Р., Долгих Е.А. Гигиеническое состояние полости рта у пациентов, находящихся на ортодонтическом лечении // Здоровье и образование в XXI веке. - 2008. - № 5.- С. 227.

10. Дробышева Н.С. Оценка ортодонтического лечения взрослых пациентов с зубочелюстными аномалиями и воспалительно-дистрофическими заболеваниями пародонта: автореф. дис. ... канд. мед. наук. - М., 2007. - 25 с.

11. Железный П.А., Русакова Е.Ю., Щелкунов К.С. [и др.] Состояние факторов местного иммунитета полости рта в процессе комплексного ортодонтического лечения // Тихоокеанский медицинский журнал.— 2013.- № 1.- С. 26-28.

12. Кирсанова Е.В., Кондратьева Н.А., Аветисян Л.М. Цифровые методики диагностики и планирования ортодонтического лечения с использованием кортикальной опоры.// Клиническая стоматология. — 2021.— № 1 (97): — С. 102-107.

13. Курбанов А.О. Зубочелюстные аномалии у взрослых, пути совершенствования организационной и лечебной помощи (эпидемиологическое и клиническое исследование): автореф. дис. ... доктора мед. наук. — Москва, 1994. — 36 с.

14. Куроедова В.Д., Макарова А.Н. Распространенность зубочелюстных аномалий у взрослых и доля асимметричных форм среди них. // «Мир Медицины и Биологии»- 2012. - № 4(35): - С. 31-35.

15. Левенц А.А., Бриль Е.А., Кожевникова Т.А. Состояние системы иммунитета у детей на этапах ортодонтического лечения // Институт стоматологии. 2005. - № 3.- - C. 44-45.

16. Маркин А.С. Распространенность зубочелюстных аномалий у лиц в возрасте 16-25 лет проживающих в г. Самара // Известия Самарского научного центра Российской академии наук. Социальные, гуманитарные, медико-биологические науки. — 2016. — № 1. — С. 121-124.

17. Мехмани И.Г., Мамедов Ф.Ю., Сафаров А.М. Влияние ортодонтического лечения на функциональное состояние органов и тканей полости рта. / Меdіх, Ліки Украін.-, 2014. — № 2 (19).

18. Мягкова Н.В. Клинико-лабораторное обоснование выбора метода ортодонтического лечения взрослых пациентов с аномалиями окклюзии и дефектами зубных рядов: автореф. дис. ... канд. мед. наук. - Екатеринбург, 2004. - 22 с.

19. Петрунина Ольга Викторовна. Клинико-цитологическая диагностика воспалительных осложнений в тканях пародонта при ортодонтическом лечении с использованием несъемной техники: автореф. дис. ... канд. мед. наук. - Моска, 2008. - 27 с.

20. Рамм, Н.Л. Кисельникова Л.П., Юркова М.А. Несъемная ортодонтическая техника — риск развития осложнений // Институт стоматологии. 2001. — No 4(13). - С. 22-25.

21. Снеткова, Н.В. Персии Л.С., Картон Е.А. Изменение микроциркуляции тканей пародонта первых постоянных моляров при использовании несъемных ортодонтических аппаратов // Ортодонтия.— 2012.— № 1.—C. 85. 
22. Соломонова А.Д. Изменение микробиоценоза полости рта у ортодонтических пациентов: дис. ... канд. мед. наук. — Новосибирск, 2007. — 135 с.

23. Хорошилкина, Ф.Я., Персии Л.С. Ортодонтия. Лечение аномалий зубов и зубных рядов современными ортодонтическими аппаратами. Клинические и технические этапы их изготовления. Книга 1. - Н. Новгород: изд-во НГМА, 2002. - 251 с.

24. Шади, Т.Э.Д. Характеристика частоты и распространенности осложнений, возникающих в процессе ортодонтического лечения несъемными аппаратами в городе Воронеже: автореф. дис. ... канд. мед. наук. - Воронеж, 2012. - 19 с.

25. Шварц А.Д. Биомеханика и окклюзия зубов. - М. Медиоефера, 1994.190 с.

26. Щелкунов К.С. Влияние несъемной ортодонтической аппаратуры на развитие воспалительных заболеваний пародонта и их коррекция: дис. ... канд. мед. наук. - Новосибирск, 2007. - 135 с.

( Керефова Зарина Витальевна ( zarinakeref@mail.ru ), Тхазаплижева Марина Тулевна ( mar_tul25@mail.ru ), Шхагапсоева Карина Аслановна ( Karina.denta@mail.ru ), Карданова Лариса Владимировна ( kard-77@yandex.ru ),

Карданова Карина Хасанбиевна ( kardanovakarina@mail.ru).

Журнал «Современная наука: актуальные проблемы теории и практики»

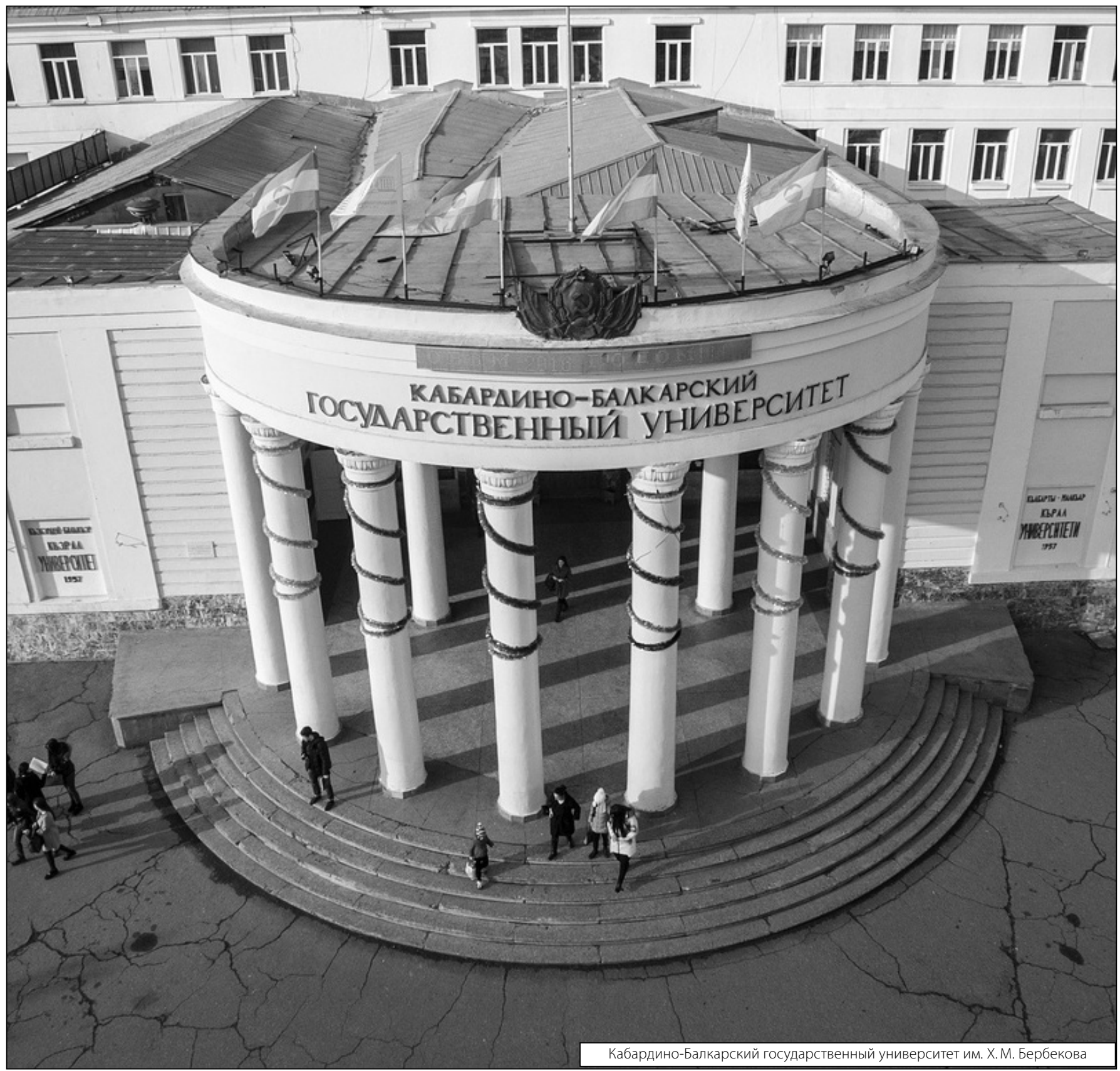

